Bull. Chem. Soc. Ethiop. 2018, 32(2), 225-238.

ISSN 1011-3924

(c) 2018 Chemical Society of Ethiopia and The Authors

Printed in Ethiopia

DOI: https://dx.doi.org/10.4314/bcse.v32i2.4

\title{
REMOVAL OF HEAVY METALS Pb(II), Cd(II) AND Cu(II) FROM WASTE WATERS USING SYNTHESIZED CHROMIUM DOPED NICKEL OXIDE NANO PARTICLES
}

\author{
Y.V.S. Sai Krishna, G. Sandhya and R. Ravichandra Babu* \\ Department of Chemistry, GITAM (Deemed to be University), Visakhapatnam, Andhra \\ Pradesh-530045, India
}

(Received April 28, 2017; Revised February 25, 2018; Accepted May 21, 2018)

\begin{abstract}
Adsorption of metal ions $\mathrm{Pb}(\mathrm{II}), \mathrm{Cd}(\mathrm{II})$ and $\mathrm{Cu}(\mathrm{II})$ are observed on chromium doped nickel nano metal oxide. Chromium doped nickel oxide was synthesized by combustion technique using glycine as a fuel. In this work, transmission electronic microscopy (TEM), scanning electronic microscopy (SEM), X-ray diffraction (XRD) and Brunauer-Emmett-Teller (BET) are applied to study the composition and structure of chromium doped nickel oxide. Batch equilibrium experiments were performed to study the removal efficiency of heavy metal ions. The effects of different parameters such as contact time, $\mathrm{pH}$ and adsorbent dose on the adsorption process were investigated. The adsorption kinetics and adsorption isotherms studies were also performed. The formation of hydroxide on the surface of chromium doped nickel oxide could be the main factor of cations removal due to its high adsorption affinity for aqueous solutes. Chromium doped nickel oxide may offer a potential remediation method for the removal of metals from water and environment.
\end{abstract}

KEY WORDS: Adsorption isotherms, BET, Adsorption efficiency, Batch equilibrium, Adsorption kinetics

\section{INTRODUCTION}

Exposure to heavy metals is one of the most severe global environment problems $[1,2]$. Industrial waste may contain toxic and heavy metals such as $\mathrm{Pd}, \mathrm{Cr}, \mathrm{Ni}, \mathrm{Cu}$ and $\mathrm{Cd}$ depending up on the type of the process and raw materials used. Heavy metals are non-biodegradable in nature [3]. Their presence even in low concentration in water is harmful to human health as well as aquatic life. Lead is a heavy metal and commonly used in households and many industries [46]. Thus industrial wastewater is considered to be a potential source of trace metal pollution [7, 8].

Recent approaches for the removal of heavy metals from wastewaters have mainly included chemical precipitation, adsorption, oxidation-reduction, evaporation, ionic exchange, electrochemical treatment, and membrane separation techniques [9-14]. Adsorption is most commonly used for heavy metals remediation from water $[15,16]$. Activated carbons, clay minerals and chitosan/natural zeolites were used to remediate heavy metals from water and waste water $[17,18]$.

Metal oxides play a very important role in many areas of chemistry, physics and materials science. The metal elements are able to form a large diversity of oxide compounds. In technological applications, oxides are used in the fabrication of microelectronic circuits, sensors, piezoelectric devices, fuel cells, coatings for the passivation of surfaces against corrosion, and as catalysts. There were several reports available in literature where in nano metal oxides and composites alone have been tried for the removal of heavy metals in waste water and ground waters [19-22].

Metal oxides of transition elements are well known to possess chemically active surfaces and large surface areas that can be employed to extract a range of ions from aqueous solutions. The properties of various metal oxides have been modified in order to change their electrical, optical, structural or thermal behaviors by doping in additional species. The aim of this study

*Corresponding author. E-mail: rrcbabu7@yahoo.in

This work is licensed under the Creative Commons Attribution 4.0 International License 
was to synthesize chromium doped nano nickel oxide by employing combustion technique using glycine as a fuel. During combustion process $\mathrm{CO}_{2}, \mathrm{H}_{2} \mathrm{O}$ and liberate heat in exothermic process and forms complexes with metal ions facilitating homogeneous mixing of the cations in solution $[23,24]$. In this study the author has made an attempt to synthesize a metal doped nano oxide which can found to be a potential adsorbent for the removal of heavy metals such as $\mathrm{Cd}, \mathrm{Cu}$ and $\mathrm{Pb}$. Sorption studies were conducted at different initial $\mathrm{pHs}$, equilibrium time, and adsorbent/adsorbate concentrations. Kinetic and isotherm adsorption models are performed in order to better understanding of the adsorption mechanism [25, 26]. Thermodynamic studies were also performed to determine the entropy, enthalpy and Gibb's free energy [27].

\section{EXPERIMENTAL}

\section{Materials and reagents}

All chemical stock solutions were prepared from reagent grade chemicals using Millipore ultrapure water. Nickel nitrate hexahydrate, chromium trioxide were purchased from Merck, India.

\section{Method of preparation}

For the synthesis of chromium doped nickel nano oxide, $0.02 \mathrm{M}$ nickel nitrate hexa hydrate and $0.2 \mathrm{M}$ glycine dissolved in a minimum amount of water. The contents were kept on a magnetic stirrer for $45 \mathrm{~min}$ until homogenous solution was obtained. After that $0.1 \mathrm{~g}$ of chromium trioxide as a source of chromium was added to the above solution and the stirring is continued for half an hour. The obtained solution was kept on a hot plate for one hour until gel type layer was formed and it is cooled. It is transferred into porcelain dish and placed in a pre-heated muffle furnace for $20 \mathrm{~min}$ at $500{ }^{\circ} \mathrm{C}$. The obtained calcined powder was ground in a mortar for $15 \mathrm{~min}$.

\section{Powder XRD analysis}

XRD characterization was performed to determine the crystalline structure of the synthesized adsorbent and the results are shown in Figure 1. The XRD scanning from 20-70 shows the lines (111), (200), (116) and (220) at $2 \Theta=37.22^{\circ}, 43.266^{\circ}, 51.725^{\circ}$, and $62.965^{\circ}$ respectively for chromium doped Nickel nano oxide as shown in Figure 1. The diffraction peaks of the particles matched with the JCPDS file $87-0712$ related to $\mathrm{NiO}$ peaks. The $2 \Theta$ value $51.725^{\circ}$ related to doped metal.

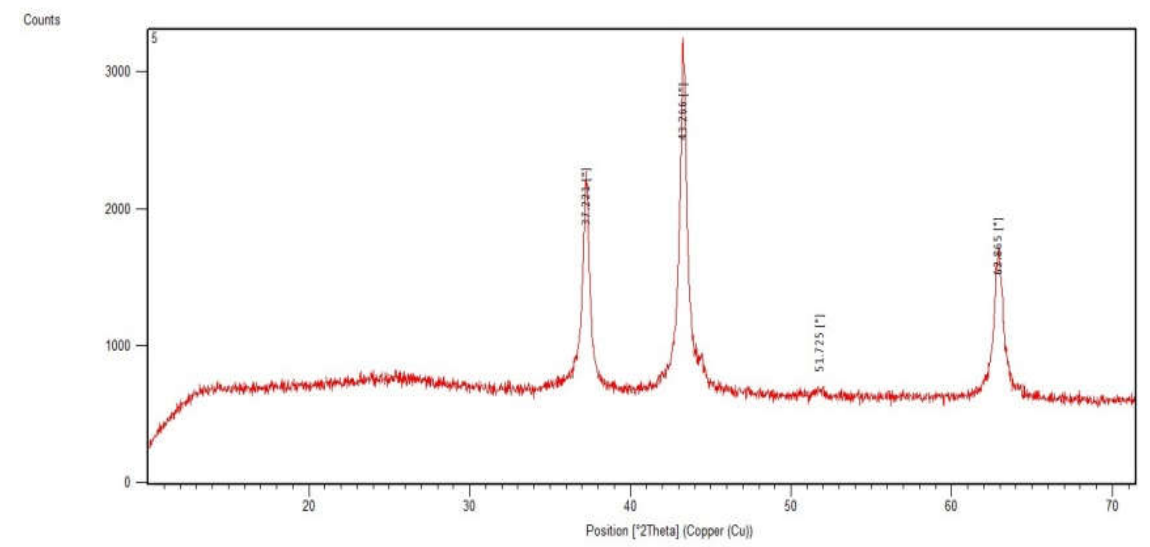

Figure 1. Powder XRD pattern of chromium doped $\mathrm{NiO}$ nanostructure.

Bull. Chem. Soc. Ethiop. 2018, 32(2) 
$\mathrm{D}=\mathrm{K} \lambda / \beta \operatorname{COS} \Theta$

where $\beta$ is the line width at half maximum peak intensity, $\lambda$ is the wave length of $\mathrm{X}$-ray $(0.154$ $\mathrm{nm}), \mathrm{K}$ is correction factor for particle shape ( 0.9 for spheres), $\mathrm{D}$ is the crystallite diameter, and $\Theta$ is the angle of incidence for the selected diffraction peak. The synthesized doped nano metal oxide was found to with an average size in between of $10 \mathrm{~nm}$ to $20 \mathrm{~nm}$. No characteristic peak related to any other impurity was observed. "PANALYTICAL" Xpert-pro X-Ray diffractometer (P-XRD) was used for X-ray diffraction studies of $\mathrm{NiO}$ nano oxide with generator settings 40 $\mathrm{kV}$ and $30 \mathrm{~mA}$ at room temperature.

\section{SEM analysis}

In order to obtain insight information about surface morphology, particle size of the samples, SEM analysis were performed. The particles are agglomerated and this agglomeration was reduced by increase the grain growth. From the SEM micrograph, the prepared crystallites are nearly spherical in shape as shown in Figure 2.

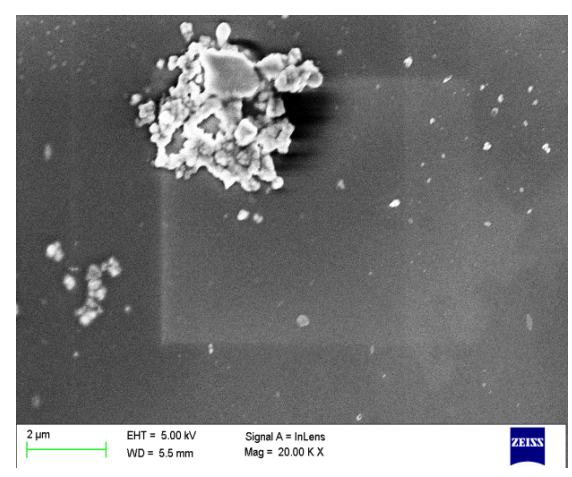

Figure 2. SEM micrograph of $\mathrm{Cr}$ doped $\mathrm{NiO}$.
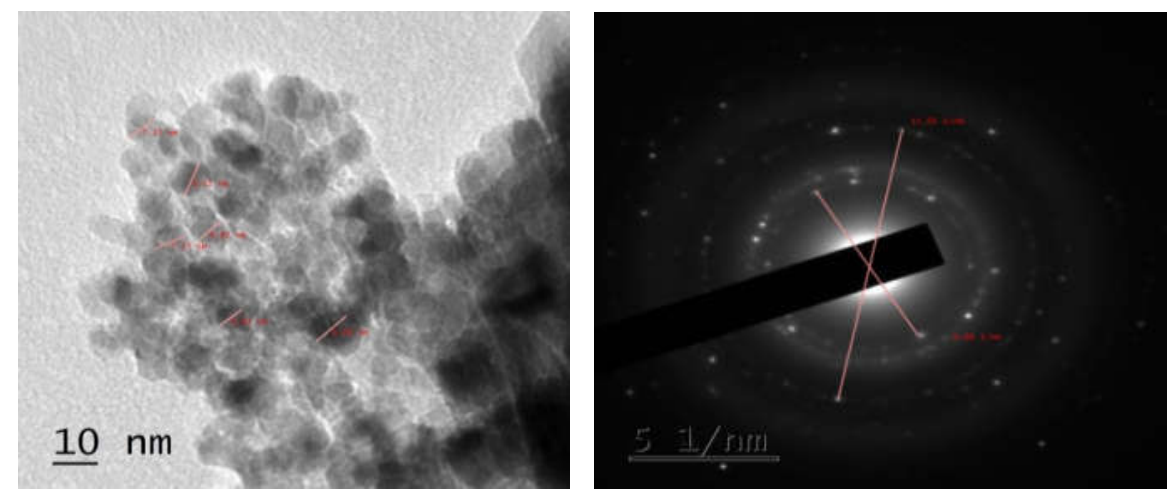

Figure 3. TEM micrograph of $\mathrm{Cr}$ doped $\mathrm{NiO}$.

\section{TEM micrograph analysis}

The transmission electron microscope (TEM) has emerged as a powerful tool for probing the structure of metals and alloys. It can give morphological information of shape and size of 
particles in a microstructure. It can also reveal the nature of crystallographic defects. TEM use low wavelength electron which makes it possible to get a high resolution image. The average crystallite size of $\mathrm{Cr}$ doped $\mathrm{NiO}$ was found to be $10 \mathrm{~nm}$ as shown in Figure 3.

\section{Brunauer-Emmett-Teller (BET) surface}

The most common method used to measure the surface area of solid materials is the BrunauerEmmett Teller (BET) method. The specific surface area of a powder is determined by physical adsorption of a gas on the surface of the solid and by calculating the amount of adsorbate gas corresponding to a monomolecular layer on the surface. By using BET we can measure directly pore size distribution and surface area. The BET surface area of chromium doped nickel oxide was found to be $76 \mathrm{~m}^{2} / \mathrm{g}$ with pore size $14 \mathrm{~nm}$ and pore volume of $0.33 \mathrm{~cm}^{3} / \mathrm{g}$.

\section{Batch experiment}

In order to study the effect of different parameters such as the contact time, $\mathrm{pH}$, and adsorbent dosage, various experiments have been carried out by agitation of known amount of adsorbent $(0.15 \mathrm{~g})$ in $30 \mathrm{~mL}$ of solution containing $\mathrm{Pb}(\mathrm{II}), \mathrm{Cd}(\mathrm{II})$ and $\mathrm{Cu}(\mathrm{II})$ ions with concentrations ranging between $0.1 \mathrm{mg} / \mathrm{L}$ to $1 \mathrm{mg} / \mathrm{L}$ on rotary shaker at a constant speed of $180 \mathrm{rpm}$ at room temperature $\left(28^{\circ} \mathrm{C}\right)$. The effect of $\mathrm{pH}$ was studied by adjusting the $\mathrm{pH}$ of solutions in the range of $2-10$ with $0.1 \mathrm{~N} \mathrm{NaOH}$ or $\mathrm{HCl}$ solutions.

The metal ions concentrations in the solution were determined by using inductively coupled plasma mass spectrometer (ICP - MS), make Agilent Technologies (Model No. 7700). The metal ion concentration retained by sorbent $(\mathrm{mg} / \mathrm{g})$ [sorption capacity $(\mathrm{Qe})$ ] and distribution coefficient $(\mathrm{D}, \mathrm{mL} / \mathrm{g})$ can be determined as follows:

$Q_{e}=\left(\mathrm{C}_{0}-\mathrm{C}_{\mathrm{e}}\right) V / m$

where $Q e$ is the equilibrium adsorption capacity $(\mathrm{mg} / \mathrm{g}), C_{0}$ and $C_{\mathrm{e}}$ are the initial and equilibrium liquid-phase concentrations of solute in aqueous solution $(\mathrm{mg} / \mathrm{L})$, respectively. $V$ is the liquid phase volume (L) and $m$ is the mass of sorbent used (g).

\section{RESULTS AND DISCUSSION}

\section{Effect of $p H$}

In batch adsorption experiments $\mathrm{pH}$ is one of the major parameter and a great significance effect on rate of adsorption and the degree of ionization of adsorbate. The effect of $\mathrm{pH}$ on the chromium doped nickel oxide was carried out by varying $\mathrm{pH}$ from 2 to 10 . While increasing the $\mathrm{pH}$ of the solution, the removal efficiency of cadmium(II), lead(II) and copper(II) metal ions considerably increased. The batch mode experiments were carried out by taking $30 \mathrm{~mL}$ of solution of trace metals $(\mathrm{Pb}, \mathrm{Cd}$ and $\mathrm{Cu})$ with a concentration of $1 \mathrm{mg} / \mathrm{L}$ and adsorbent dose 0.15 $\mathrm{g}$ and contact time of $45 \mathrm{~min}$. It is noticed that the maximum percentage removal of trace metals were obtained in basic $\mathrm{pH}$ range, i.e. $\mathrm{pH}$ at 9.0. The results are reported in Figure 4.

\section{Effect of contact time}

The effect of contact time on adsorption of trace metals ( $\mathrm{Pb}(\mathrm{II}), \mathrm{Cd}$ (II) and $\mathrm{Cu}$ (II)) onto chromium doped nickel oxide is shown in Figure 5. For chromium doped nickel oxide adsoprtion efficiency is about $99.6 \%$ for lead ions, $97.9 \%$ for cadmium ions and $97.8 \%$ for copper ions. The optimum condition of contact time is attanied at $45 \mathrm{~min}$ at constant adsorbent dose $0.15 \mathrm{~g}$ and it was still constant for remaining time period, i.e. $60,80,120 \mathrm{~min}$, respectively. The concentration of metal ions in the batch mode process was $1 \mathrm{mg} / \mathrm{L}$. 


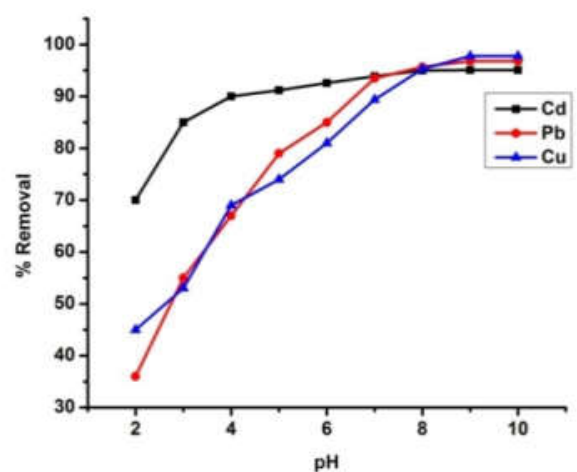

Figure 4. Effect of $\mathrm{pH}$ on $\mathrm{Cd}(\mathrm{II}), \mathrm{Pb}(\mathrm{II})$ and $\mathrm{Cu}(\mathrm{II})$ adsorption.

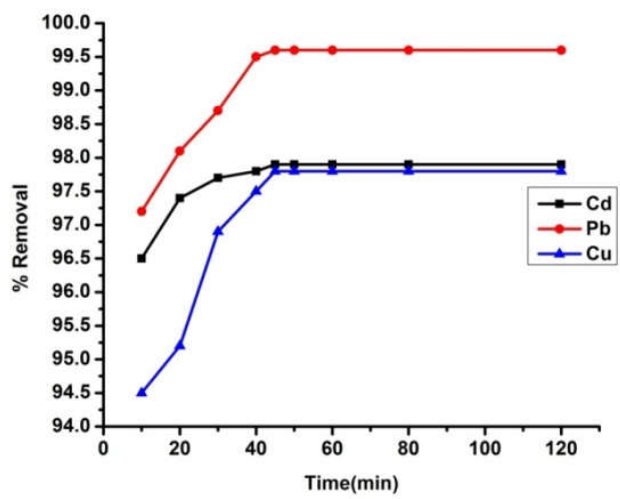

Figure 5. Effect of contact time on $\mathrm{Cd}(\mathrm{II}), \mathrm{Pb}(\mathrm{II})$ and $\mathrm{Cu}(\mathrm{II})$ adsorption.

\section{Effect of amount of adsorbent}

The effect of amount of chromium doped $\mathrm{NiO}$ was studied by carrying out experiments using 30 $\mathrm{mL}$ of trace metals $(\mathrm{Pb}, \mathrm{Cd}$ and $\mathrm{Cu})$ with a concentration of $1 \mathrm{mg} / \mathrm{L}$ with a dosage ranging from $0.05 \mathrm{~g}$ to $0.5 \mathrm{~g}$ (Figure 6). The percentage removal efficiency of trace metals increased up to $99 \%$ with the increase in the amount of dosage up to $0.15 \mathrm{~g}$ of adsorbent and then remained constant with increase in the adsorbent dose. Removal \% of trace metals increased rapidly till maximum removal is attained at optimum dosage, i.e. $0.15 \mathrm{~g}$ because of high availability of exchangeable sites. The effect of various parameters such as $\mathrm{pH}$, contact time and adsorbent dosage is given in Table 1.

Table 1. Optimum conditions for adsorption of metal onto chromium doped NiO.

\begin{tabular}{|l|c|c|c|}
\hline Parameters & $\mathrm{Cd}(\mathrm{II})$ & $\mathrm{Pb}(\mathrm{II})$ & $\mathrm{Cu}(\mathrm{II})$ \\
\hline $\mathrm{pH}$ & 9.0 & 9.0 & 9.0 \\
\hline Contact time (min) & 45 & 45 & 45 \\
\hline Adsorbent dose (g) & 0.15 & 0.15 & 0.15 \\
\hline
\end{tabular}




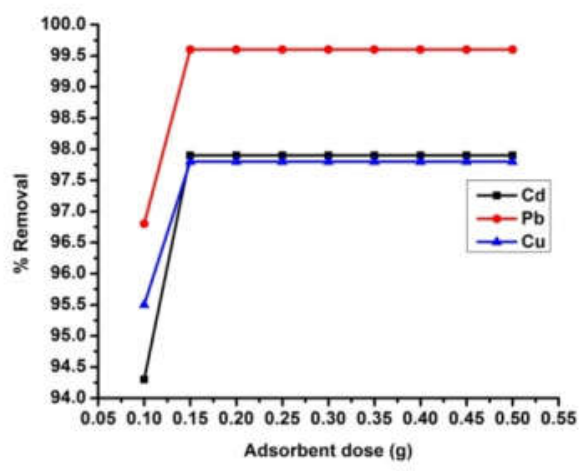

Figure 6. Effect of adsorbent dose on $\mathrm{Cd}(\mathrm{II}), \mathrm{Pb}(\mathrm{II})$ and $\mathrm{Cu}(\mathrm{II})$ adsorption.

\section{Sorption process}

It was additionally shown that the powder material synthesized via solution combustion route has negative surface charge over the whole $\mathrm{pH}$ range studied (Figure 7). According to the literature $[28,29]$, low $\mathrm{pH}$ values are unfavorable for metal ion adsorption, since in that range they are present in solution in free form as $\mathrm{M}^{\mathrm{n+}}\left(\mathrm{Cd}^{2+}, \mathrm{Cu}^{2+}\right.$ and $\left.\mathrm{Pb}^{2+}\right)$, hence in this case there is an electrostatic repulsion between the cation and the more positively charged surface of the adsorbent. With increasing $\mathrm{pH}$, the adsorbent surface becomes more negatively charged more $\mathrm{OH}^{-}$groups are generated and this fact allows metal ions, such as $\mathrm{Cd}(\mathrm{II}), \mathrm{Pb}(\mathrm{II})$, and $\mathrm{Cu}(\mathrm{II})$ to be adsorbed more effectively. In a strongly basic environment, the anions $\mathrm{M}(\mathrm{OH})^{-}$are formed, and these forms of metal ions, like cadmium or lead hydroxides, strongly interact with the surface of the inorganic oxide adsorbent, making adsorption easier.

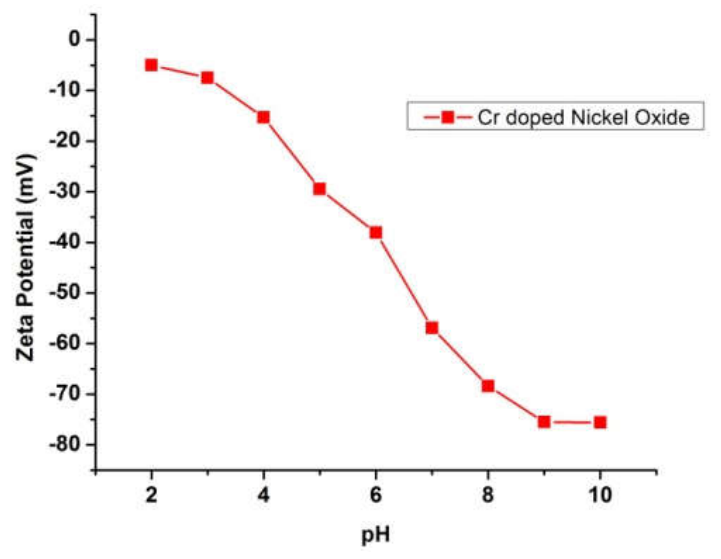

Figure 7. Metal ions $(\mathrm{Pb}, \mathrm{Cd}$ and $\mathrm{Cu})$ interation with chromium doped $\mathrm{NiO}$ adsorbent surface atdiffernt $\mathrm{pH}$ values.

Adsorption isotherm

The interaction between solutes and sorbents is well described in an adsorption isotherm. For the design and optimization of adsorption process, developing an appropriate isotherm model 
viz., Langmuir adsorption isotherm, Freundlich adsorption isotherm, Temkin adsorption isotherm and D-R isotherms for the adsorption is required. However, the equilibrium adsorption isotherms play a vital role in calculating the adsorption capacity of metal ions and diagnosing the nature of adsorption onto chromium doped $\mathrm{NiO}$ nanometal oxide. The information gained from this present work was checked with Langmuir, Freundlich, Temkin and D-R models.

\section{Langmuir isotherm}

This isotherm method is one of the widely used for explaining the adsorption of solutes onto a solid substance in a solution. With the formation of monolayer coverage of adsorbates on adsorbents, the adsorption takes place on finite number of adsorption sites and was given in the following equation.

$\mathrm{q}_{\mathrm{e}}=\mathrm{q}_{\mathrm{m}} \mathrm{K}_{\mathrm{L}} \mathrm{C}_{\mathrm{e}} /\left(1+\mathrm{K}_{\mathrm{L}} \mathrm{C}_{\mathrm{e}}\right)$

The linearized form of Langmuir can be written as follows

$\mathrm{C}_{\mathrm{e}} / \mathrm{q}_{\mathrm{e}}=1 / \mathrm{q}_{\mathrm{m}} \mathrm{K}_{\mathrm{L}}+\mathrm{C}_{\mathrm{e}} / \mathrm{q}_{\mathrm{m}}$

where $\mathrm{q}_{\mathrm{e}}$ is the solid-phase equilibrium concentration $\left(\mathrm{mg} \mathrm{g}^{-1}\right) ; \mathrm{C}_{\mathrm{e}}$ is the liquid equilibrium concentration of heavy metals $(\mathrm{Pb}, \mathrm{Cd}, \mathrm{Cu})$ in solution $\left(\mathrm{mg} \mathrm{L}^{-1}\right) ; \mathrm{K}_{\mathrm{L}}$ is the equilibrium constant related to the affinity of binding sites $\left(\mathrm{L} \mathrm{mg}^{-1}\right)$; and $\mathrm{q}_{\mathrm{m}}$ is the maximum amount of the heavy metals $(\mathrm{Pb}, \mathrm{Cd}, \mathrm{Cu})$ per unit weight of adsorbent for complete monolayer coverage (Figure 8).

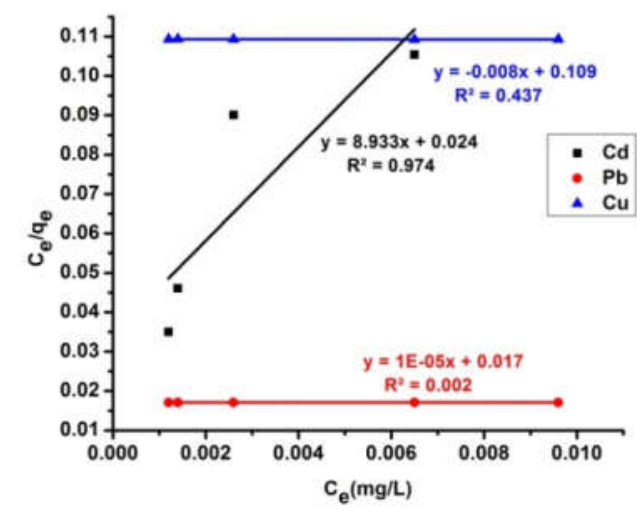

Figure 8. Langmuir adsorption isotherm of $\mathrm{Pb}(\mathrm{II}), \mathrm{Cd}(\mathrm{II})$ and $\mathrm{Cu}(\mathrm{II})$ onto $\mathrm{Cr}$ doped $\mathrm{NiO}$ nanostructure.

\section{Freundlich isotherm}

The Freundlich isotherm describes adsorption where the adsorbent has a heterogeneous surface with adsorption sites that have different energies of adsorption. The energy of adsorption varies as a function of the surface coverage $\left(\mathrm{q}_{\mathrm{e}}\right)$ and is represented by Freundlich constant $\mathrm{K}_{\mathrm{F}}\left(\mathrm{L} \mathrm{g}^{-1}\right)$ in Equation:

$\mathrm{q}_{\mathrm{e}}=\mathrm{K}_{\mathrm{F}} \mathrm{C}_{\mathrm{e}}^{\mathrm{n}}$

where $\mathrm{K}_{\mathrm{F}}$ is roughly an indicator of the adsorption capacity and $\mathrm{n}$ is the heterogeneity factor which has a lower value for more heterogeneous surfaces. In most references, Freundlich adsorption Eq. (5) may also be expressed as

$\ln \mathrm{q}_{\mathrm{e}}=\ln \mathrm{K}_{\mathrm{F}}+1 / \mathrm{n}_{\mathrm{e}}$ 
All the correlation coefficients, $\mathrm{R}^{2}$ value, and the constants obtained for the models show that the Langmuir and Freundlich isotherms fitted with cadmium(II) and only Freundlich isotherm fitted with lead(II) and copper(II) ions. Freundlich isotherm is suitable equation to describe the adsorption equilibrium of heavy metals $(\mathrm{Pb}, \mathrm{Cd}, \mathrm{Cu})$ on the $\mathrm{Cr}$ doped $\mathrm{NiO}$ (Figure 9).

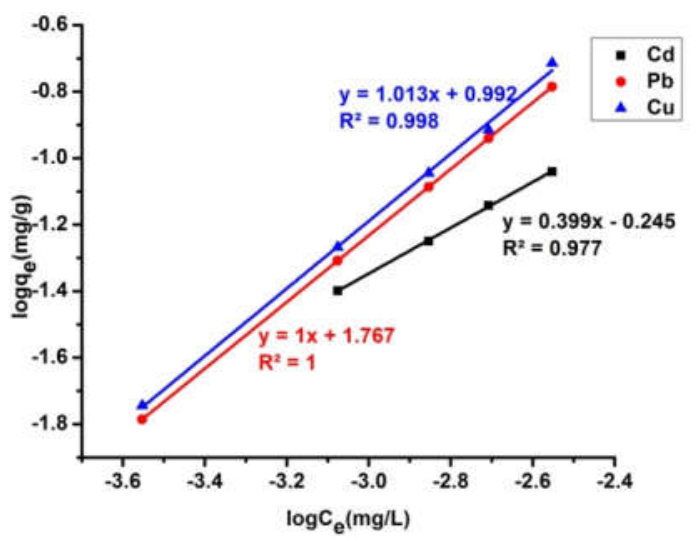

Figure 9. Freundlich adsorption isotherm of $\mathrm{Pb}(\mathrm{II}), \mathrm{Cd}(\mathrm{II})$ and $\mathrm{Cu}(\mathrm{II})$ onto $\mathrm{Cr}$ doped $\mathrm{NiO}$ nanostructure.

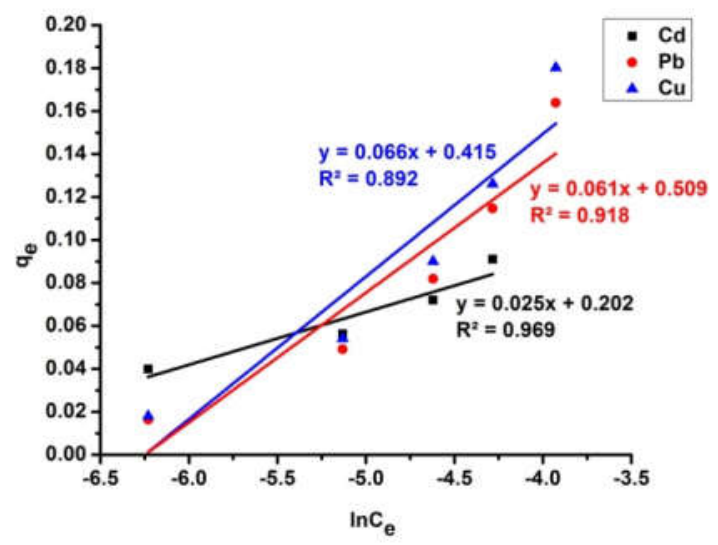

Figure 10. Temkin adsorption isotherm of $\mathrm{Pb}(\mathrm{II}), \mathrm{Cd}(\mathrm{II})$ and $\mathrm{Cu}(\mathrm{II})$ onto $\mathrm{Cr}$ doped $\mathrm{NiO}$ nanostructure

Temkin isotherm

The Temkin isotherm contains a factor that explicitly takes into account the adsorbing speciesadsorbate interactions; the isotherm is given by a linearized expression as

$\mathrm{q}_{\mathrm{e}}=\mathrm{RT} / \mathrm{b}_{\mathrm{t}} \ln \mathrm{A}_{\mathrm{t}}+\mathrm{RT} / \mathrm{b}_{\mathrm{t}} \ln \mathrm{C}_{\mathrm{e}}$

where $B_{T}=R T / b$ ( $R$ is the universal gas constant $(8.314 \mathrm{~J} / \mathrm{mol} \mathrm{K})$, T is temperature $(K)$, BT is the Temkin constant related to adsorption energy $(\mathrm{kJ} / \mathrm{mol})$, and $\mathrm{K}_{\mathrm{T}}$ is the binding constant at 
equilibrium corresponding to the maximum binding energy $(\mathrm{L} / \mathrm{mg})$. The values of $\mathrm{K}_{\mathrm{T}}$ and $\mathrm{B}_{\mathrm{T}}$ were calculated from the intercept and slope of the plot of $\mathrm{q}_{\mathrm{e}} \mathrm{vs}$. $\ln \mathrm{C}_{\mathrm{e}}$ (Figure 10).

Dubinin-Radushkevich isotherm model

The nature of adsorption can be also determined by analyzing the equilibrium data using the Dubinin-Radushkevich model (D-R). The D-R model is generally applied to express the adsorption mechanism with a Gaussian energy distribution onto a heterogeneous surface. The model has often been shown to fit both high activities of the solute and the intermediate range of concentrations. The adsorption energy is evaluated on the basis of the Dubinin-Radushkevich equation. $\mathrm{D}-\mathrm{R}$ adsorption isotherm of $\mathrm{Pb}(\mathrm{II}), \mathrm{Cd}(\mathrm{II})$ and $\mathrm{Cu}$ (II) onto $\mathrm{Cr}$ doped $\mathrm{NiO}$ nanostructure is shown in Figure 11.

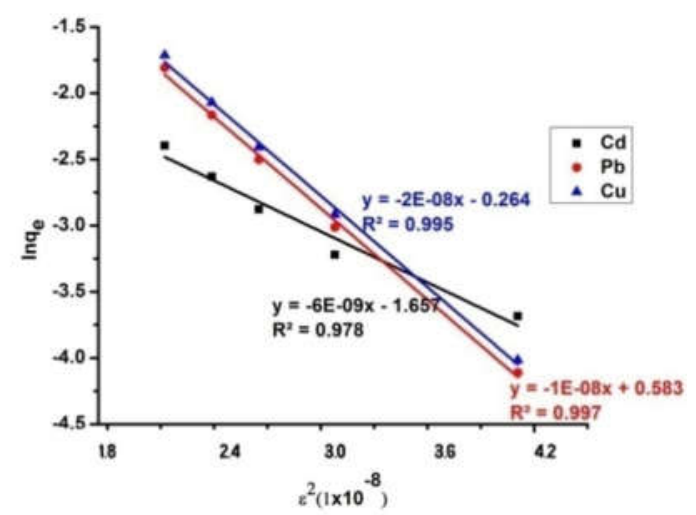

Figure 11. D-R adsorption isotherm of $\mathrm{Pb}(\mathrm{II}), \mathrm{Cd}(\mathrm{II})$ and $\mathrm{Cu}(\mathrm{II})$ onto $\mathrm{Cr}$ doped $\mathrm{NiO}$ nanostructure

The data related to adsorption isotherms are given in Table 2.

Table 2. Adsorption isotherm models of cadium(II), lead(II) and copper(II) ions using chromium doped nickel oxide nano particles.

\begin{tabular}{|c|c|c|c|c|}
\hline Isotherm model & Parameters & $\mathrm{Cd}(\mathrm{II})$ & $\mathrm{Pb}$ (II) & $\mathrm{Cu}(\mathrm{II})$ \\
\hline \multirow[t]{3}{*}{ Langmuir model } & $\mathrm{Qm}(\mathrm{mg} / \mathrm{g})$ & 0.1119 & - & -125 \\
\hline & $\mathrm{K}_{\mathrm{L}}(\mathrm{L} / \mathrm{mg})$ & 372.3 & - & 0.07339 \\
\hline & $\mathrm{R}^{2}$ & 0.974 & 0.002 & 0.437 \\
\hline \multirow[t]{4}{*}{ Freundlich model } & $1 / \mathrm{n}$ & 0.399 & 0.987 & 1.013 \\
\hline & $\mathrm{n}$ & 2.506 & 1.013 & 0.987 \\
\hline & $\mathrm{Kf}(\mathrm{mg} / \mathrm{g})$ & 1.75 & 58.4 & 9.817 \\
\hline & $\mathrm{R}^{2}$ & 0.971 & 1 & 0.998 \\
\hline \multirow[t]{4}{*}{ D-R model } & $\mathrm{Q}_{\mathrm{m}}(\mathrm{mg} / \mathrm{g})$ & 5.243 & 1.7914 & 1.3021 \\
\hline & $\beta\left(\mathrm{mol}^{2} / \mathrm{kJ}^{2}\right)$ & $6 \times 10^{-9}$ & $1 \times 10^{-8}$ & $2 \times 10^{-8}$ \\
\hline & $\mathrm{E}\left(\mathrm{kJmol}^{-1}\right)$ & 9.1 & 7.0 & 5.0 \\
\hline & $\mathrm{R}^{2}$ & 0.977 & 0.997 & 0.995 \\
\hline \multirow[t]{4}{*}{ Temkin } & $\mathrm{A}_{\mathrm{t}}(\mathrm{L} / \mathrm{mg})$ & 3229.23 & 4205.7 & 537.96 \\
\hline & $\mathrm{B}$ & 0.025 & 0.061 & 0.066 \\
\hline & bt & 99102.88 & 40615.9 & 37538.93 \\
\hline & $\mathrm{R}^{2}$ & 0.969 & 0.918 & 0.892 \\
\hline
\end{tabular}

Bull. Chem. Soc. Ethiop. 2018, 32(2) 
Kinetics of adsorption

The main aim of adsorption kinetics is to determine the rate-determining step. To set up an equilibrium time and rate of sorption of contaminants in solution, the uptake of adsorbates as function of time is usually taken. Adsorption mechanisms or dynamics were generally checked by substituting the experimental values of adsorption in the kinetic models. The following discussed four kinetic models viz., pseudo first and second order, intraparticle diffusion and Elovich model, were the general models used for explaining, solid-liquid adsorption systems.

\section{Pseudo first order model}

In order to predict adsorption kinetic model, pseudo-first-order and pseudo-second-order kinetic models were applied to the data. The pseudo first-order model assumes that the rate of change of solute uptake with time is directly proportional to difference in saturation concentration and amount of solid uptake with time.

$\ln \left(\mathrm{q}_{\mathrm{e}}-\mathrm{q}_{\mathrm{t}}\right)=\ln \mathrm{q}_{\mathrm{e}}-\mathrm{k}_{1} \mathrm{t}$

where $\mathrm{q}_{\mathrm{e}}$ and $\mathrm{q}_{\mathrm{t}}$ are the amounts of heavy metals adsorbed per unit mass of the adsorbent $\left(\mathrm{mg} \mathrm{g}^{-1}\right)$ at equilibrium and time $\mathrm{t}$, respectively, and $\mathrm{k}_{1}$ is the rate constant of adsorption $\left(\mathrm{min}^{-1}\right)$. When $\ln \left(\mathrm{q}_{\mathrm{e}}-\mathrm{q}_{\mathrm{t}}\right)$ was plotted against time, a straight line should be obtained with a slope of $-\mathrm{k}_{1}$, if the first-order kinetics is valid. Figure 12 represents pseudo first order reaction.

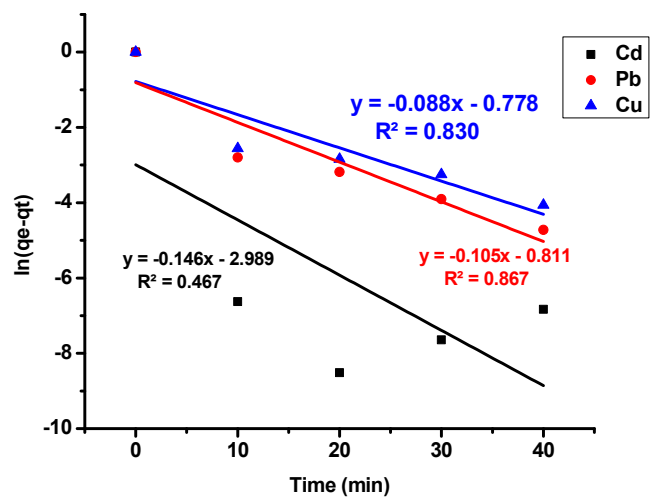

Figure 12. Kinetic pseudo first order reaction of $\mathrm{Cr}$ doped $\mathrm{NiO}$.

Pseudo second order model

The pseudo-second-order model is in the following form:

$\mathrm{t} / \mathrm{q}_{\mathrm{t}}=\mathrm{t} / \mathrm{q}_{\mathrm{e}}+1 /\left(\mathrm{k}_{2} \mathrm{q}_{\mathrm{e}}^{2}\right)$

where $\mathrm{q}_{\mathrm{e}}$ and $\mathrm{q}_{\mathrm{t}}$ represent the amount of heavy metals adsorbed $\left(\mathrm{mg} \mathrm{g}^{-1}\right)$ at equilibrium and at any time, $\mathrm{k}_{2}$ in the rate constant of the pseudo-second-order equation $\left(\mathrm{g} \mathrm{mg}^{-1} \mathrm{~min}^{-1}\right)$. A plot of $t / q_{t}$ versus time ( $t$ ) would yield a line with a slope of $1 / q_{e}$ and an intercept of $1 /\left(k_{2} q_{e}^{2}\right)$, if the second-order model is a suitable expression. The plot between $\ln \left(q_{e}-q_{t}\right)$ versus time t shows the pseudo-first-order model and the plot of t/qe versus time $t$ shows the pseudo-second-order model. 
The kinetic model with a higher correlation coefficient $\mathrm{R}^{2}$ was selected as the most suitable one. It was found that application of pseudo-second-order kinetics provides better correlation coefficient of experimental data than the pseudo-first-order model for the heavy metals $(\mathrm{Pb}, \mathrm{Cd}$, $\mathrm{Cu}$ ) onto adsorbent. The good correlation coefficients were obtained by fitting the experimental data to Eq. (8), indicating that the adsorption process on $\mathrm{Cr}$ doped $\mathrm{NiO}$ is pseudo second order. The pseudo second-order kinetic model was found to be appropriate for describing kinetics of metal adsorption. The values of rate constant were calculated from the slope of the Figures 13.

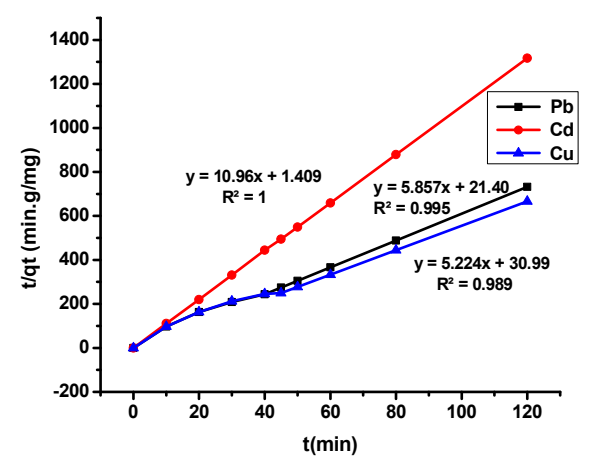

Figure 13. Kinetic pseudo second order reaction of $\mathrm{Cr}$ doped $\mathrm{NiO}$.

Elovich kinetic model

The Elovich kinetic model generally expressed as

$\mathrm{q}_{\mathrm{t}}=1 / \beta \ln \alpha \beta+1 / \beta \ln \mathrm{l}$

where $\alpha$ is the initial adsorption rate ( $\mathrm{mg} / \mathrm{g} \cdot \mathrm{min}), \beta$ is the desorption constant $(\mathrm{g} / \mathrm{mg})$ during any experiment. A plot of $\mathrm{q}_{\mathrm{t}} \mathrm{vs} \ln (\mathrm{t})$ should give a straight line where in $1 / \beta$ and $1 / \beta \ln (\alpha \beta)$ correspond to the slope and intercept. Its use is currently adapted for the modeling of experimental data obtained for aqueous solutions. Elovich kinetic model of $\mathrm{Cr}$ doped $\mathrm{NiO}$ is shown in Figure 14.

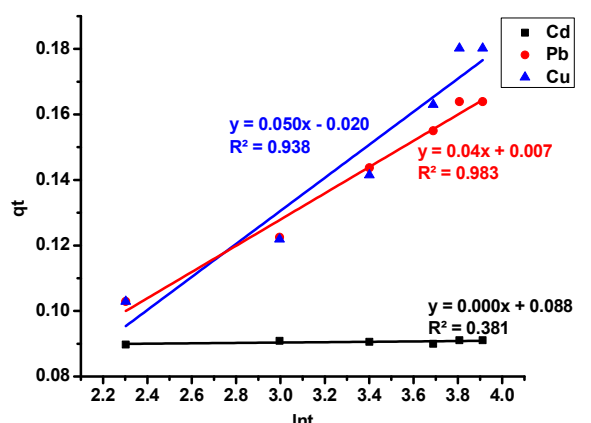

Int

Figure 14. Elovich kinetic model of $\mathrm{Cr}$ doped $\mathrm{NiO}$. 
Intraparticle diffusion

Intraparticle diffusion describes the movement of species from the bulk of the solution to the solid phase. The possibility of intra-particle diffusion resistance was identified using the following intra-particle diffusion model.

$\mathrm{q}_{\mathrm{t}}=\mathrm{k}_{\mathrm{i}} \mathrm{t}^{0.5}+\mathrm{C}$

where $C$ is constant and $k_{i}$ is the intra particle diffusion rate constant $\left(\mathrm{mg} / \mathrm{g} \mathrm{min}{ }^{1 / 2}\right), q_{t}(\mathrm{mg} / \mathrm{g})$ is the amount adsorbed at a time, $\mathrm{t}^{1 / 2}$ is the square root of time $\left(\mathrm{min}^{1 / 2}\right)$. The intra particle diffusion rate constant was determined from the slope of the linear plot $q_{t}$ versus $t^{1 / 2}$ (Figure 15). The larger the intercept, greater is the contribution of the surface adsorption in the rate limiting step. The data and results related to the adsorption kinetics are given in Table 3.

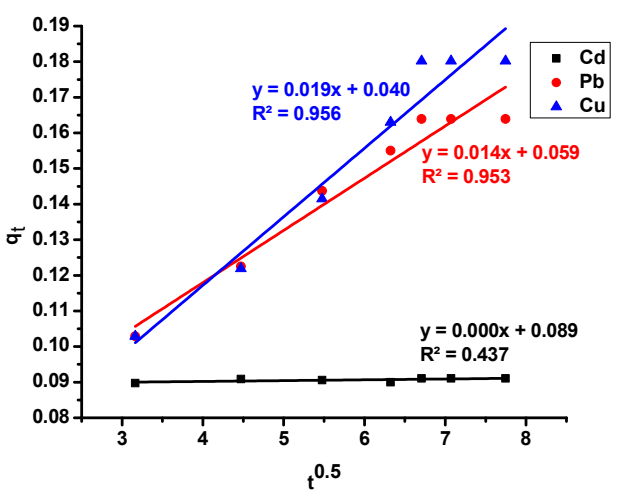

Figure 15. Intraparticle diffusion model of $\mathrm{Cr}$ doped $\mathrm{NiO}$.

Table 3. Adsorption kinetic parameters of $\mathrm{Pb}^{2+}, \mathrm{Cd}^{2+}, \mathrm{Cu}^{2+}$ by $\mathrm{Cr}$ doped $\mathrm{NiO}$ particle.

\begin{tabular}{|c|c|c|c|c|}
\hline Kinetic model & Parameters & $\mathrm{Cd}(\mathrm{II})$ & $\mathrm{Pb}(\mathrm{II})$ & $\mathrm{Cu}(\mathrm{II})$ \\
\hline \multirow{4}{*}{$\begin{array}{l}\text { Pseudo kinetic } \\
\text { first order }\end{array}$} & $\mathrm{K}_{1}$ & 0.146 & -0.105 & -0.088 \\
\hline & Cal Q $(\mathrm{mg} / \mathrm{g})$ & 0.05033 & 0.444 & 0.459 \\
\hline & Exp. $Q_{e}(\mathrm{mg} / \mathrm{g})$ & 0.09108 & 0.1639 & 0.1802 \\
\hline & $\mathrm{R}^{2}$ & 0.467 & 0.867 & 0.830 \\
\hline \multirow{4}{*}{$\begin{array}{l}\text { Pseudo kinetic } \\
\text { second order }\end{array}$} & $\mathrm{K}_{2}$ & 85.6 & 1.7398 & 0.9937 \\
\hline & Cal Qe $(\mathrm{mg} / \mathrm{g})$ & 0.09124 & 5.857 & 5.224 \\
\hline & Exp. $Q_{\mathrm{e}}(\mathrm{mg} / \mathrm{g})$ & 0.09108 & 6.1012 & 5.549 \\
\hline & $\mathrm{R}^{2}$ & 1 & 0.995 & 0.989 \\
\hline \multirow[t]{3}{*}{ Elovich model } & $\alpha$ & - & 20.9 & 29.8 \\
\hline & $\beta$ & - & 25 & 20 \\
\hline & $\mathrm{R}^{2}$ & - & 0.983 & 0.938 \\
\hline \multirow[t]{2}{*}{ Intraparticle diffusion } & $\mathrm{K}_{\mathrm{id}}$ & - & 0.014 & 0.019 \\
\hline & $\mathrm{R}^{2}$ & 0.437 & 0.953 & 0.956 \\
\hline
\end{tabular}

\section{CONCLUSION}

Adsorption of metal ions $\mathrm{Pb}(\mathrm{II}), \mathrm{Cd}(\mathrm{II})$ and $\mathrm{Cu}(\mathrm{II})$ on chromium doped nickel nano metal oxide was examined. Chromium-doped nickel oxide was synthesized by combustion technique using glycine as a fuel. In this work, transmission electronic microscopy (TEM), scanning electronic microscopy (SEM) and X-ray diffraction (XRD) were applied to study the compositional and structural information of chromium doped nickel oxide. Brunauer-Emmett-Teller (BET) studies 
were used to measure the surface area. The BET surface area of $\mathrm{Cr}$ doped nickel oxide was found to be $76 \mathrm{~m}^{2} / \mathrm{g}$. Batch equilibrium experiments were performed to study the removal efficiency of metal ions $\mathrm{Pb}(\mathrm{II}), \mathrm{Cd}(\mathrm{II})$ and $\mathrm{Cu}(\mathrm{II})$. The effects of different parameters such as contact time, $\mathrm{pH}$ and adsorbate dose on the adsorption process were investigated. The adsorption kinetics well fitted using a pseudo-second-order kinetic model. SEM and TEM images showed that of particles was mostly agglomerated with an average size $10 \mathrm{~nm}$. Adsorption isotherms studies are also performed. The results from Freundlich isotherm shows that the system can be comfortably applicable for the removal of the $\mathrm{Cd}(\mathrm{II}), \mathrm{Pb}$ (II) and $\mathrm{Cu}(\mathrm{II})$ metals at a concentration range of $0.1-1.0 \mathrm{mg} / \mathrm{L}$. The $\mathrm{K}_{\mathrm{F}}$ value of lead ion is higher than that of cadmium and copper, so adsorption is more efficient towards lead ion. From the kinetic studies, pseudo second order well fitted with the obtained data, i.e. experimental value good agreement with calculated value and also correlation coefficient $R^{2}$ values are nearly equal to 1 . This study confirms adsorption process was controlled by chemisorption process. The formation of hydroxide on the surface of chromium doped nickel oxide could be the main factor of cations removal due to its high adsorption affinity for aqueous solutes. The thermodynamic parameter $\Delta \mathrm{G}^{\mathrm{o}}$ value shows that the removal of heavy metals lead(II), cadmium(II), and copper(II) ions from aqueous solutions by using chromium doped nickel oxide nanoparticles was spontaneous in nature and $\Delta \mathrm{S}^{\mathrm{o}}$ values for above metal ions shows an increase in the disorder of the solidsolution interface during adsorption at $298 \mathrm{~K}$. The $\Delta \mathrm{H}^{\circ}$ value indicates that the process is endothermic in nature. Chromium-doped nickel oxide may offer a potential remediation method for the removal of metals from water and environment.

\section{ACKNOWLEDGEMENTS}

Funding from University Grants Commission (UGC), New Delhi, Government of India in the form of Major Research Project (Project F.No:42-327/2013(SR)) is gratefully acknowledged. The authors are thankful to the STIC Cochin for providing TEM facility and to Institute of Physics, Bhubaneswar for providing SEM facility. The authors are thankful to Department of Chemistry, GITAM University for providing atomic absorption spectrophotometer (AAS) facility procured from DST-FIST. The authors are thankful to Andhra University for providing [inductively coupled plasma mass spectrometry] ICP-MS facility.

\section{REFERENCES}

1. Fu, F.; Wang, Q. Removal of heavy metal ions from wastewaters: A review. J. Environ. Manage. 2011, 92, 407-418.

2. Hua, M.; Zhang, S.; Pan, B.; Zhang, W.; Lv, L.; Zhang, Q. Heavy metal removal from water/wastewater by nanosized metal oxides: A review J. Hazard. Mater. 2012, 211, $317-$ 331.

3. Jarup, L.; Hazards of heavy metal contamination. British Med. Bull. 2003, 68, 167-182.

4. Jamil, M.; Zia, M.S.; Qasim, M. Contamination of agro-ecosystem and human health hazards from waste water used for irrigation. J. Chem. Soc. Pak. 2010, 32, 370-378.

5. Khan, S.; Cao, Q.; Zheng, Y.; Huang, Y.; Zhu, Y. Health risks of heavy metals in contaminated soils and food crops irrigated with wastewater in Beijing, China. Chin. Environ. Poll. 2008, 152, 686-692.

6. Tesfaw, B.; Chekol, F.; Mehretie, S.; Admassie, S. Adsorption of $\mathrm{Pb}(\mathrm{II})$ ions from aqueous solution using lignin from Hagenia abyssinica. Bull. Chem. Soc. Ethiop. 2016, 30, 473-484.

7. Chen, J.Z.; Tao, X.C.; Xu, J.; Zhang, T.; Liu, Z.L. Biosorption of cadmium and mercury by immobolized Microcystis aeruginosa in a column. Proc. Biochem. 2005, 40, 3675-3679.

8. Meena, A.K. Removal of heavy metal ions from aqueous solutions using carbon aerogel as an adsorbent. J. Hazard. Mater. 2005, 122, 161-170. 
9. Flores, V.; Cabassud, C. A hybrid membrane process for $\mathrm{Cu}(\mathrm{II})$ removal from industrial wastewater comparison with a conventional process system. Desalination 1999, 126, 101108.

10. Mobasherpour, I.; Salahi, E.; Pazouki, M. Removal of divalent cadmium cations by means of synthetic nano crystallite hydroxyapatite. Desalination 2011, 266, 142-148.

11. Rahmani, A.; Zavvar Mosavi, H.; Fazli, M. Effect of nanostructure alumina on adsorption of heavy metals. Desalination. 2010, 253, 94-100.

12. Xing, Y.; Chen, X.; Wang, D. Electrically regenerated ion exchange for removal and recovery of Cr(VI) from wastewater. Environ. Sci. Technol. 2007, 41, 1439-1443.

13. Ersahin, M.E.; Ozgun, H.; Dereli, R.K.; Ozturk, I.; Roest, K.; Van Lier, J.B. A review on dynamic membrane filtration: Materials, applications and future perspectives. Biores. Technol. 2012, 122, 196-206.

14. Bodalo-Santoyo, A.; Gómez-Carrasco, J.L.; Gomez-Gomez, E.; Maximo-Martin, F. Application of reverse osmosis to reduce pollutants present in industrial wastewater. Desalination. 2003, 155, 101-108.

15. Gupta, S.; Bhattacharyya, K.G. Adsorption of metal ions by clays and inorganic solids RSC $A d v$. 2014, 4, 28537-28586.

16. Walsh, F.C.; Reade, G.W. Electrochemical techniques for the treatment of dilute metal-ion solutions. Stud. Environ. Sci. 1994, 59, 3-44.

17. Bailey, S.E., Olin, T.J., Bricka, R.M.; Adrian, D.D. A review of potentially low-cost sorbents for heavy metals. Wat. Res. 1999, 33, 2469-2479.

18. Wang, X.; Zheng, Y.; Wang, A. Fast removal of copper ions from aqueous solution by chitosan-g-poly(acrylic acid)/attapulgite composites. J. Hazard. Mater. 2009, 168, 970-977.

19. Wang, L.; Li, J.; Jiang, Q.; Zhao, L. Water-soluble $\mathrm{Fe}_{3} \mathrm{O}_{4}$ nanoparticles with high solubility for removal of heavy-metal ions from waste water. Dalton Trans. 2012, 41, 4544-4551.

20. Xu, P.; Zeng, G.M.; Huang, D.L.; Feng, C.L.; Hu, S.; Zhao, M.H.; Lai, C.; Wei, Z.; Huang, C.; Xie, G.X. Use of iron oxide nanomaterials in wastewater treatment: A review. Sci. Total Environ. 2012, 424, 1-10.

21. Ge, F.; Li, M.M.; Ye, H.; Zhao, B.X. Effective removal of heavy metal ions $\mathrm{Cd}^{2+}, \mathrm{Zn}^{2+}, \mathrm{Pb}^{2+}$, $\mathrm{Cu}^{2+}$ from aqueous solution by polymer-modified magnetic nanoparticles. J. Hazard. Mater. 2012, 211, 366-372.

22. Feng, Y.; Gong, J.L.; Zeng, G.M.; Niu, Q.Y.; Zhang, H.Y.; Niu, C.G.; Deng, J.H.; Yan, M. Adsorption of $\mathrm{Cd}(\mathrm{II})$ and $\mathrm{Zn}$ (II) from aqueous solutions using magnetic hydroxyapatite nanoparticles as adsorbents. Chem. Eng. J. 2010, 162, 487-494.

23. Biamino, S.; Paolo, F.; Matteo, P.; Badini, C. Alumina-zirconia-yttria nanocomposites prepared by solution combustion synthesis. Ceram. Int. 2006, 32, 509-513.

24. McKittrick, J.; Sheab, L.E.; Bacalskia, C.F.; Bosze, E.J. The influence of processing parameters on luminescent oxides produced by combustion synthesis. Displays 1999, 19, 169-172.

25. Wibulswas, R. Bach and fixed bed sorption of methylene blue on precursor and QUACs modified montmorillonite. Sep. Purif. Technol. 2004, 39, 3-12

26. Alam, S.; Rehman, N.; Amin, N.; Shah, L.A.; Mian, I.; Ullah, H. Removal of basic green 5 by carbonaceous adsorbent: Adsorption kinetics. Bull. Chem. Soc. Ethiop. 2017, 31, 411422.

27. Zhu, X.; Lan, L.; Xiang, N.; Liu, W.; Zhao, Q.; Li, H. Thermodynamic studies on the adsorption of $\mathrm{Cu}^{2+}, \mathrm{Ni}^{2+}$ and $\mathrm{Cd}^{2+}$ on to amine-modified bentonite. Bull. Chem. Soc. Ethiop. 2016, 30, 357-367.

28. Karthik, R.; Meenakshi, S. Chemical modification of chitin with polypyrrole for the uptake of $\mathrm{Pb}(\mathrm{II})$ and $\mathrm{Cd}(\mathrm{II})$ ions. Int. J. Biol. Macromol. 2015, 78, 157-164.

29. Karthik, R.; Meenakshi, S. Removal of $\mathrm{Pb}(\mathrm{II})$ and $\mathrm{Cd}(\mathrm{II})$ ions from aqueous solution using polyaniline grafted chitosan. Chem .Eng. J. 2015, 263, 168-177. 